\title{
Identifying Associations between Sport Sponsorship Decision-Making Variables
}

\author{
$\mathbf{C} \mathbf{H}$ van Heerden and $\mathbf{P} \mathbf{J}$ du Plessis
}

Department of Marketing and Communication Management, University of Pretoria

\begin{abstract}
Sport sponsorship spending in South Africa has increased steadily. This paper discusses the findings of an exploratory study into key sponsorship decision-areas, namely the setting of sponsorship objectives, the integration of marketing communication variables into sponsorship to create a leverage effect, and the measurement of sponsorship success. It is argued that for a sponsorship to be successful certain associations should exist between these key decision-making areas and also among elements internal to each of these areas. The main findings are that the respondents indicated a bias towards setting media related objectives that will subsequently enable the sponsors to use media-related measurement tools. It is recommended that sponsors should develop alternative methods to measure the effectiveness of their sponsorships.
\end{abstract}

JEL L83, M31, 39

\section{1 \\ Introduction}

Sponsorship in South Africa is an important marketing tool considering that 14 per cent of all marketing expenditure in South Africa is spent on sponsorship or event management (Grobler as quoted by Koenderman, 2000: 86). In addition sponsorship spending holds substantial spin-offs for the advertising fraternity, generating an almost equal additional amount in terms of supporting promotions and advertising expenditure.

Grobler as quoted by Koenderman (2000: 86) calculated that the direct sponsorship and sponsorship back-up expenditure in 1998 was R1.63 billion compared to the total South African advertising expenditure of R4.9 billion. Eyles (2001: 3) estimates the latter to have ranged between R5.6 billion and R6.3 billion in 2001. Figures quoted by Van Heerden (2003: 2) estimate that total sponsorship spending increased to close to R2.7 billion in 2002. Despite evidence of a substantial growth in sport sponsorship expenditure, a lack of research reports on South African sponsorship decision-making is still noticeable.

It is argued that three key decision-making areas are important to sponsorship managers. First, a sponsor should set clear objectives. Secondly, a sponsor has to leverage the sponsorship expenditure by integrating other marketing communication tools such as advertising, sales promotion, publicity, and marketing public relations into the sponsorship to increase the effectiveness of the sponsorship. Lastly, the sponsor needs to measure the eventual effectiveness of the sponsorship.

This paper reports the findings of an exploratory investigation into the importance of particular variables in these three key sport sponsorship decision-making areas, namely objective setting, leveraging and measurement, and whether associations or relationships exist between individual variables or groups of variables included in the three key areas. 
Theoretical framework

\section{Figure 1}

A sport sponsorship decision-making framework

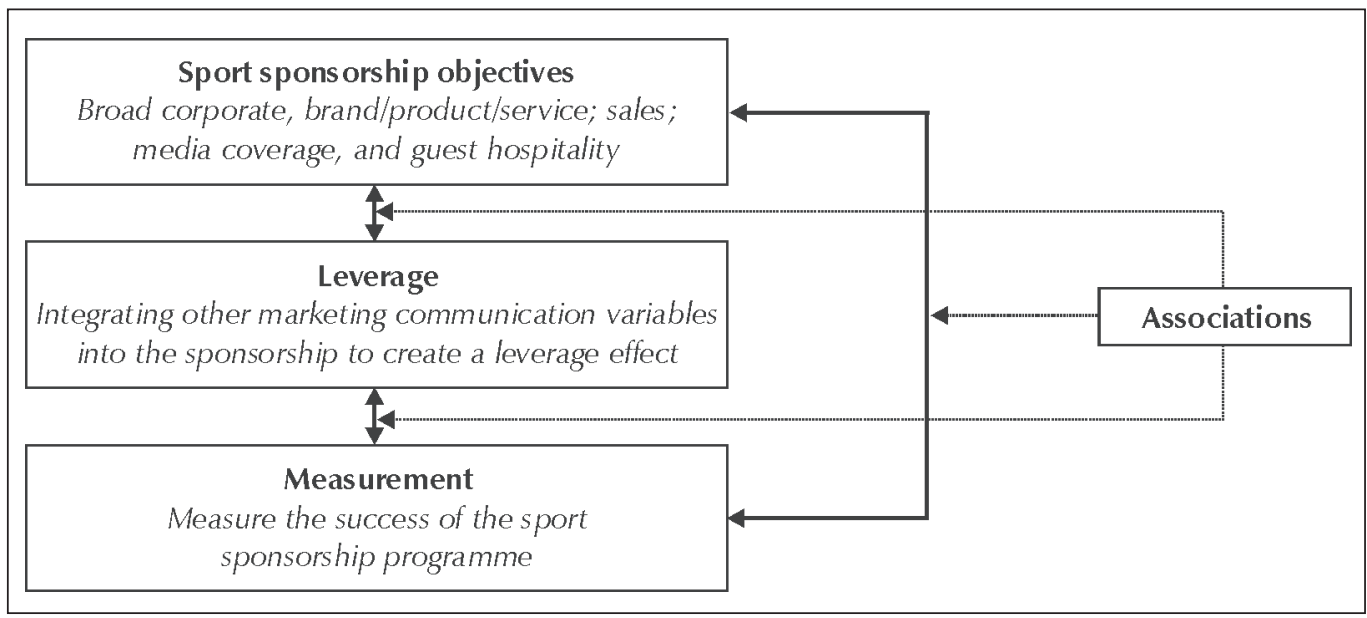

A framework that illustrates three key sponsorship decision-making areas is depicted in Figure 1. Sponsorship objectives should be set in such a way the eventual effects of the sponsorship can be measured. Sponsorship can not be successful on its own, so other marketing communication variables such as advertising, sales promotion, publicity and marketing public relations should be integrated into the sponsorship to create a leverage effect. Such leverage would enhance the return on sponsorship investment. Associations may also exist between elements internally to a construct such as leverage where different marketing communication variables are integrated into a sponsorship i.e. are there stronger associations between sponsorship and advertising than between sponsorship and marketing public relations. Associations between the importance and use of measurement tools should also be determined.

\section{Key decision-making area 1: Sport} sponsorship objectives

Judging by the available number of views, most notably those of Shandler \& Shani (1993), Irwin \& Sutton (1994), Cornwell \& Maignan (1998), and Pope (1998) on sponsorship objectives, it is assumed that this area of sport sponsorship decision-making has been extensively analysed by researchers, academics and practitioners world-wide. Clearly defined, quantifiable sponsorship objectives provide the best guidance to selecting the events or activities to sponsor, enabling the sponsor to develop clear sponsor opportunity selection criteria and to eventually measure the effectiveness of the sponsorship programme.

\section{Key decision-making area 2: Leverage}

Sponsorship, isolated from the other elements of the marketing communication mix, would not be effective, as those other elements are required to leverage the sponsorship programme. Similarly, the other elements of the communications mix should link into the sponsorship programme and to each other enabling the promotion plan, as a whole, to flow into achieving the overall corporate, marketing, and marketing communication objectives.

Meenaghan (1991: 8) argues that because sponsorship is largely a 'mute and non-verbal medium', it should be used in conjunction with traditional advertising (i.e., tied in with other 
marketing communication variables). Failure to do so would mean that a full exploitation of the sponsorship's possibilities could not be guaranteed, and this would leave open the opportunity for competitors to sabotage the sponsorship (Meenaghan, 1994: 77 and 1996: 103). Various authors such as Jobber (1995: 454), Shimp (1997: 566) and Brassington \& Pettitt (2000: 814) imply that sponsorship should be leveraged with other marketing communication variables to maximise the effectiveness of sponsorship expenditure.

\section{Key decision-making area 3: Measurement}

Hoek (in Kitchen, 1999: 367) refers to several researchers such as Witcher, Craigen, Culligen \& Harvey (1991) and Quester \& Burton (1997) who have noted that, although sponsorship objectives have been well documented, research into sponsorship evaluation has remained inadequate. It is therefore not surprising that Speed \& Thompson (1997: 266) conclude "models identifying factors that influence a sponsorship's success lag far behind those seen in other areas of promotion".

Javalgi, Traylor, Cross \& Lampman (1994) as cited by Hoek (in Kitchen, 1999: 367) and Pope (1998: 1) observed that most researchers agree that evaluation is imperative, especially given the scale of investment now occurring.

Various authors have identified and discussed (and often criticised) various categories of measurement tools. The following list summarises the main categories identified in sport sponsorship literature:

- Product/brand related measurement (Jeannet \& Hennessey, 1988; Irwin \& Asimakopoulos, 1992; and Stotlar, 1993);

- Media audits (Abratt, Clayton \& Pitt, 1987; Sleight, 1989; Parker, 1991; Marshall \& Cook, 1992; Meenaghan, 1994; Crimmins \& Horn, 1996; Pope, 1998; and Hoek in Kitchen, 1999);

- Recognition, recall and awareness (Stotlar \& Johnson, 1989; Cuneen \& Hannan, 1993; Sandler \& Shani, 1993; Javalgi, Traylor, Cross \& Lampman, 1994; d'Astous \& Bitz, 1995; Shilbury \& Berriman, 1996; Pope \& Voges, 1997; and Hoek in Kitchen, 1999);
- Image and attitude (Abratt \& Grobler, 1989; Sleight, 1989; Parker, 1991; Javalgi et al., 1994; Rajaretnam, 1994; d'Astous \& Bitz, 1995; Hansen \& Scotwin, 1995; Stipp \& Schiavone, 1996; Hoek in Kitchen, 1999); and

- Behavioural measures (Hoek in Kitchen, 1999).

The associations between all the key decisionmaking areas have never been specifically stated in international sport sponsorship literature. No study in South Africa has ever been reported on sponsorship measurement. The aim of this study is inter alia to uncover which measurement tools are favoured by local sponsors.

\section{Identifying possible associations between the key decision-making areas}

Strategies for leveraging the sponsorship can be developed directly from sponsorship objectives. Clear and measurable sponsorship objectives also allow for focussing, during implementation, and enable effective evaluation of whether sponsorship "success" has been achieved. Thwaites (1995: 152) argues that: "measures of exposure, awareness, image, sales effectiveness and guest hospitality are possible", but concludes that "objectives often appear to be imprecise and are not developed in a form that allows subsequent evaluation".

The view that objective setting and evaluation procedures should be linked and be devised at the same stage in the sponsorship decision process has also been proposed by Sleight (1989: 110) and Arani (1992: 7-12) who argue that by linking evaluation directly to objective setting, anticipated results can be formulated. It therefore has to be assumed that there should be a strong association between setting objectives and measuring whether those objectives have been met.

\section{3}

\section{Research objectives}

The main aim of the study is to uncover any associations between the three key decisionmaking areas. Due to the exploratory nature of the study, no formal hypotheses will be 
proposed. A few exploratory research propositions are postulated:

Proposition 1a: Identify the most important sport sponsorship objectives set by the respondents

Proposition 1b: Identify the most important marketing communication variables integrated into sport sponsorships by the respondents

Proposition 1c: Identify the most important sport sponsorship measurement tools utilised by the respondents

Proposition 2: Test for possible associations between any of the three decision-making variables or between individual and/or groups of variables internal to any of the three key areas.

\section{4}

\section{Research methodology}

The main objective of testing the framework, proposed in Figure 1, is to determine the importance of factors affecting sport sponsorship decision-making in South Africa and to test for associations between the three key decision-making areas.

All 180 members of the Association of Marketers (ASOM - now falling under a new body, namely the Marketing Federation of South Africa - the only professional marketing body in South Africa), that represents most of the important corporate marketing decisionmakers in South Africa, were surveyed on their opinions about the importance of a number of sport sponsorship constructs by means of a selfadministered questionnaire. Forty-three completed questionnaires were returned, while thirty-seven ASOM-members indicated that they are not involved in sport sponsorship. The aim of the study was not to determine differences in attitude, opinions or sponsorship practices between the different respondents. The group was treated as a homogenous population in terms of their membership of ASOM and them being sport sponsorship managers.
The questionnaire consisted of three sections. The first section, relating to key decisionmaking area 1 in Figure 1, contained a list of sport sponsorship objective variables. The list of sport sponsorship objectives was divided into five main categories, namely corporate, brand/ product/service, sales, media coverage, and guest hospitality, as identified by Sandler \& Shani (1993: 38-43).

The second section, relating to key decisionmaking area 2 in Figure 1, consisted of a list of marketing communication variables that could possibly be used as leverage tools. The list was based on the general acceptance that available marketing communication tools include advertising, sales promotion, personal selling, publicity, public relations and direct marketing. The third section, relating to key decisionmaking area 3 in Figure 1, containing a list of possible measurement tool variables, was also based on tools listed in sport sponsorship literature.

A 5-point Likert scale was used to test the relative importance, from not important to very important of each of the variables in the questionnaire.

\section{4 Research findings}

Due to space limitations, only those variables that had a significant score will be discussed. Propositions 1a, 1b, and 1c are addressed in Tables 1 to 4 .

\section{Table 1}

Main categories of sport sponsorship objectives

\begin{tabular}{|l|c|c|}
\hline Category & $\begin{array}{c}\text { Average } \\
\text { mean* }\end{array}$ & SD \\
\hline Media & 4.26 & 0.6 \\
\hline $\begin{array}{l}\text { Marketing (Product/brand/ } \\
\text { service) }\end{array}$ & 4.22 & 0.59 \\
\hline Marketing (Sales) & 3.96 & 0.8 \\
\hline Broad corporate & 3.88 & 0.57 \\
\hline Guest hospitality & 3.66 & 0.87 \\
\hline
\end{tabular}

* An average mean score was calculated for all the statements in each category 
Basic descriptive statistics revealed that the most important objectives set by South African sponsors are media and product/brand/servicerelated (Table 1). Each category listed in Table 1 consisted of a number of objective variables. These variables are listed in Table 2.

\section{Table 2}

Individual variables (mean score $\geq 4.5$ )

Media objectives
Media coverage during the event
Increase overall media attention
Pre-event media coverage

Product/brand/service-related objectives

Strengthen brand preference

Build image within the target market (positioning)

Increase target market awareness

Increase market share

Support brand advertising

Broad corporate objectives

Promoting the corporate image

No sales or guest hospitality objectives scored $>4.5$

The most important marketing communication variables that South African sponsors integrate into their sport sponsorships to enhance leveraging opportunities are depicted in Table 3.

\section{Table 3}

Marketing communication variables that are integrated into sport sponsorships

(mean score $>4.00)$

\begin{tabular}{|l|c|c|}
\hline $\begin{array}{l}\text { Marketing communication } \\
\text { variables }\end{array}$ & Mean & SD \\
\hline Outdoor signage at the event & 4.38 & 0.87 \\
\hline The corporate logo & 4.37 & 1.27 \\
\hline Product/service/brand advertising & 4.34 & 0.84 \\
\hline Corporate image advertising & 4.24 & 1.20 \\
\hline Publicity activities & 4.21 & 0.72 \\
\hline Branded clothing items & 4.10 & 0.97 \\
\hline $\begin{array}{l}\text { Corporate public relations } \\
\text { activities }\end{array}$ & 4.02 & 0.88 \\
\hline
\end{tabular}

The following seems noteworthy from Table 3, namely the high ranking (mean $\geq 4.0$ ) of outdoor signage, the corporate logo, product/ service/brand advertising, corporate image advertising, publicity activities, branded clothing items and corporate public relations indicates that sponsors place a high premium on visual branding. The range of measurement tools that South African sponsors regard as important and the extent to which those tools are used to measure the effectiveness of their sponsorships, are outlined in Table 4.

\section{Table 4}

Sport sponsorship measurement tools in ranking order according to use (mean score $>3.5$ )

\begin{tabular}{|l|c|c|}
\hline $\begin{array}{l}\text { Sport sponsorship } \\
\text { measurement tools }\end{array}$ & $\begin{array}{c}\text { Tools } \\
\text { utilised } \\
\text { (mean } \\
\mathbf{2 3 . 5}\end{array}$ & $\begin{array}{c}\text { Importance } \\
\text { (mean } \\
\mathbf{2 4 . 0})\end{array}$ \\
\hline Media reach & 3.88 & 4.38 \\
\hline $\begin{array}{l}\text { Viewership demographics } \\
\text { (segments, profiles, figures) }\end{array}$ & 3.78 & 4.25 \\
\hline $\begin{array}{l}\text { Target market reach } \\
\text { effectiveness }\end{array}$ & 3.76 & 4.45 \\
\hline $\begin{array}{l}\text { Physical exposure of } \\
\text { company branding }\end{array}$ & 3.70 & 4.32 \\
\hline Pre-event media coverage & 3.68 & 4.29 \\
\hline $\begin{array}{l}\text { TV exposure value } \\
\text { (time } \times \text { advertising rates } \\
\text { for 30 sec) }\end{array}$ & 3.67 & 4.38 \\
\hline $\begin{array}{l}\text { Product/brand/service } \\
\text { awareness }\end{array}$ & 3.61 & 4.29 \\
\hline $\begin{array}{l}\text { Listenership demographics } \\
\text { (segments, profiles, figures) }\end{array}$ & 3.58 & 4.10 \\
\hline $\begin{array}{l}\text { Return on investment } \\
\text { in Rand value }\end{array}$ & 3.53 & 4.50 \\
\hline
\end{tabular}

Most variables listed in Table 4 are media coverage-related sport sponsorship measurement tools. It can be argued that physical exposure of company branding might indirectly be measured through television coverage. All measurement tools listed in Table 4 have a high mean score in terms of importance. Return on investment is rated as very important but scored lower on use, which might indicate that sponsors are not clear on how to measure return on investment. 
5

\section{Correlation analysis}

Another objective of this study was to find associations (through statistical testing of the responses) that can be applied to the framework depicted by Figure 1. For example, the analysis examined whether respondents related (or associated) the importance of particular sponsorship objectives categories with the importance and use of particular sponsorship measurement tools.

Burns \& Bush (1998: 551-5) state that Pearson Correlation Coefficients are calculated to detect relevant associations between variables or groups of variables. A score (pvalue) must also be evaluated to determine the probability that the correlation $\boldsymbol{r}$ falls within a desired significant level (previously accepted at 5 per cent where $\alpha=0.05$ ). The correlation coefficient $\boldsymbol{r}$ is an index number, constrained to fall between the range of -1.0 and +1.0 that communicates both the strength and the direction of association between two variables.
The Rules of Thumb proposed by Burns \& Bush (1998: 551-5) and the $\alpha$ suggested by Aczel (1999: 270) were followed and those correlation coefficients where $r \geq 0.6000$ and $\mathrm{p}<0.05$ (significance level of 5 per cent where $\alpha=0.05$ ) were used to determine moderate to strong associations between variables. "Moderate" starts at \pm 0.61 and ends at \pm 0.8 while "strong" starts at \pm 0.81 . The author noted a gap in the Rules of Thumb between "moderate" and "strong" depicted by an arithmetic gap between \pm 0.8 and \pm 0.81 . It was in any case decided to regard all $\boldsymbol{r}$ scores of $\geq 0.6$ as being significant from a moderate to strong correlation perspective and would be included in the discussion.

A subsequent correlation analysis was done to search for appropriate meaning - possible relationships or associations - based on the opinions expressed by the respondents. These associations are now discussed.

Tables 5 to 10 summarise the main findings of the descriptive statistics and the correlation analysis and addresses Proposition 2. Figure 2 depicts a summary of all associations uncovered in this study.

\subsection{Individual variable-to-variable correlation}

\section{Table 5}

Correlation between individual sport sponsorship measurement tools and individual corporate sport sponsorship objectives

\begin{tabular}{|l|l|c|}
\hline $\begin{array}{l}\text { Sport sponsorship objectives variables } \\
\text { correlate with... }\end{array}$ & $\ldots$ sport sponsorship measurement variable & $\begin{array}{c}r \geq \mathbf{0 . 6} \\
\mathbf{p = 0 . 0 0 0 1} \\
\text { (strength) }\end{array}$ \\
\hline \multicolumn{1}{|c|}{ Corporate sport sponsorship objectives } & $\begin{array}{c}0.62656 \\
\text { (moderate) }\end{array}$ \\
\hline Increase public awareness of the company & Continuity of publicity after the event & $\begin{array}{c}0.63496 \\
\text { (moderate) }\end{array}$ \\
\hline Increase public awareness of the company & Physical exposure of company branding & $\begin{array}{c}0.62656 \\
\text { (moderate) }\end{array}$ \\
\hline Change public perception of the company & Continuity of publicity after the event & $\begin{array}{c}0.72090 \\
\text { (moderate) }\end{array}$ \\
\hline Promoting corporate image & Physical exposure of company branding & \\
\hline
\end{tabular}

Table 5 illustrates that the respondents indicated a moderate association between the importance of:

- Increasing public awareness of the company, Changing public perception of the company, and Promoting corporate image as sport sponsorship variables within the category of broad corporate sport sponsorship objectives; and 
- The importance of the following sport sponsorship measurement tools, namely Continuity of publicity after the event and Physical exposure of company branding.
It can be deduced that sport sponsorship is an important awareness builder, corporate image tool and a publicity-generating vehicle.

\section{Table 6}

Correlation between individual sport sponsorship measurement tools and individual product/brand/service sport sponsorship objectives

\begin{tabular}{|c|c|c|}
\hline \multicolumn{3}{|c|}{ Product/brand/service-related sport sponsorship objectives } \\
\hline $\begin{array}{l}\text { Sport sponsorship objective } \\
\text { variables correlate with... }\end{array}$ & ...sport sponsorship measurement variable & $\begin{array}{c}r \geq 0.6 \\
p=0.0001 \\
\text { (strength) }\end{array}$ \\
\hline Increase target market awareness & Pre-event media coverage & $\begin{array}{c}0.67722 \\
\text { (moderate) }\end{array}$ \\
\hline Increase target market awareness & $\begin{array}{l}\text { Successful integration between different } \\
\text { sponsorships }\end{array}$ & $\begin{array}{c}0.61261 \\
\text { (moderate) }\end{array}$ \\
\hline Increase market share & Cross impact between sponsorships and sales & $\begin{array}{c}0.65104 \\
\text { (moderate) }\end{array}$ \\
\hline Increase market share & $\begin{array}{l}\text { Cross impact between sponsorships and } \\
\text { direct marketing }\end{array}$ & $\begin{array}{c}0.63246 \\
\text { (moderate) }\end{array}$ \\
\hline Strengthen brand preference & Product/brand/service awareness & $\begin{array}{c}0.71749 \\
\text { (moderate) }\end{array}$ \\
\hline
\end{tabular}

Table 6 depicts that the respondents indicated a moderate association between the importance of:

- Increase target market awareness with the importance of Pre-event media coverage AND the Successful integration between different sponsorships;

- Increase market share with the importance of Cross impact between sponsorships and sales AND the Cross impact between sponsorships and direct marketing,
- Strengthen brand preference with the importance of Product/brand/service awareness.

Media coverage again emerges as an important measurement tool - even within the range of product/brand/service-related sport sponsorship objectives. The correlation relating to statements on cross-impact indicates the link between sport sponsorship objectives, leverage through cross-impact and sport sponsorship measurement. These correlations also indicate the importance of measuring awareness, market share and brand preference.

\section{Table 7}

Correlation between individual sport sponsorship measurement tools and individual sales-related sport sponsorship objectives

\begin{tabular}{|l|l|c|}
\hline \multicolumn{3}{|c|}{ Sales-related sponsorship objectives } \\
\hline Sport sponsorship objective correlate with... & ...Sport sponsorship measurement variable & $\begin{array}{c}\boldsymbol{r} \geq \mathbf{0 . 6} \\
\mathbf{p = 0 . 0 0 0 1} \\
\text { (strength) }\end{array}$ \\
\hline Gain new customers & Cross impact between sponsorships and sales & $\begin{array}{c}0.70685 \\
\text { (moderate) }\end{array}$ \\
\hline To aid the sales promotion drive & Cross impact between sponsorships and sales & $\begin{array}{c}0.68123 \\
\text { (moderate) }\end{array}$ \\
\hline
\end{tabular}




\begin{tabular}{|l|l|c|}
\hline To aid the sales promotion drive & $\begin{array}{l}\text { Cross impact between sponsorships and } \\
\text { sales promotion }\end{array}$ & $\begin{array}{c}0.65015 \\
\text { (moderate) }\end{array}$ \\
\hline To aid the sales promotion drive & $\begin{array}{l}\text { Cross impact between sponsorships and } \\
\text { advertising }\end{array}$ & $\begin{array}{c}0.65677 \\
\text { (moderate) }\end{array}$ \\
\hline
\end{tabular}

The findings in Table 7 show the following moderate correlations between:

- The ability to gain new customers and measuring the effect of the sponsorship on sales through a cross-impact; and

- Aid the sales promotion drive as a sport sponsorship objective and Cross-impact between sponsorships and sales AND Cross impact between sponsorships and sales promotion AND Cross impact between sponsorships and advertising.

The correlation with the statements on crossimpact also confirms the link between sport sponsorship objectives, leverage through crossimpact and sport sponsorship measurement.

Moderate correlations are illustrated in Table 8 between:

- Increase overall media attention, and To get coverage in a diverse range of media as sport sponsorship objectives AND the corresponding sport sponsorship measurement tools - Continuity of publicity after the event, Spectator figures, Physical exposure of company branding, and Physical exposure of company branding.

\section{Table 8}

Correlation between individual sport sponsorship measurement tools and individual media coverage sport sponsorship objectives

\begin{tabular}{|c|c|c|}
\hline \multicolumn{3}{|c|}{ Media coverage-related sport sponsorship objectives } \\
\hline $\begin{array}{l}\text { Sport sponsorship objective correlate with... } \\
p=0.0001 \text { (strength) }\end{array}$ & ...Sport sponsorship measurement variable & $r \geq 0.6$ \\
\hline Increase overall media attention & Continuity of publicity after the event & $\begin{array}{c}0.66421 \\
\text { (moderate) }\end{array}$ \\
\hline Increase overall media attention & Spectator figures & $\begin{array}{c}0.69082 \\
\text { (moderate) }\end{array}$ \\
\hline To get coverage in a diverse range of media & Physical exposure of company branding & $\begin{array}{c}0.64960 \\
\text { (moderate) }\end{array}$ \\
\hline Increase overall media attention & Physical exposure of company branding & $\begin{array}{c}0.76870 \\
\text { (moderate) }\end{array}$ \\
\hline
\end{tabular}

These correlations illustrate the importance of media coverage and attention by continuous publicity, company branding and the number of people that watch the sporting event. It can be assumed that spectator figures were understood by the respondents to include viewers, readers and listeners - hence its importance as a measurement tool in association with media-related objectives.

It must be noted that the sport sponsorship measurement tool variable, Physical exposure of company branding correlated with sport sponsorship objectives (in the category Mediacoverage objectives). This may indicate that media coverage is important to sponsors to ensure that their company branding is exposed to their target markets.

Table 9 indicates that a strong correlation was detected between the importance and use of measuring the Cross-impact between sponsorships and public relations, while moderate correlations were evident between the importance and use of media (Television and Radio) exposure measurement tools. This 
alludes to a bias towards using tools that measure public relations and media effects. The researcher is not sure whether many respondents perhaps have equated publicity as being similar to public relations, which might explain the importance they place on measuring the crossimpact with public relations.

\section{Table 9}

Correlation between sport sponsorship evaluation variables (use and importance)

\begin{tabular}{|l|l|c|}
\hline $\begin{array}{l}\text { Variable / statement } \\
\text { (importance) correlate with.... }\end{array}$ & ...variable / statement (use) & $\begin{array}{c}\mathbf{r} \geq \mathbf{0 . 6} \\
\mathbf{p}=\mathbf{0 . 0 0 0 1} \\
\text { (strength) }\end{array}$ \\
\hline $\begin{array}{l}\text { TV exposure value (time } \times \text { advertising rates } \\
\text { for } 30 \text { sec) (Importance) }\end{array}$ & $\begin{array}{l}\text { TV exposure value ( time x advertising } \\
\text { rates for 30 sec) (Use) }\end{array}$ & $\begin{array}{c}0.66255 \\
\text { (moderate) }\end{array}$ \\
\hline $\begin{array}{l}\text { Radio exposure value (time x advertising rates } \\
\text { for } 30 \text { sec) (Importance) }\end{array}$ & $\begin{array}{l}\text { Radio exposure value (time x advertising } \\
\text { rates for 30 sec) (Use) }\end{array}$ & $\begin{array}{c}0.62095 \\
\text { (moderate) }\end{array}$ \\
\hline $\begin{array}{l}\text { Cross impact between sponsorships and public } \\
\text { relations (Importance) }\end{array}$ & $\begin{array}{l}\text { Cross impact between sponsorships and } \\
\text { public relations (Use) }\end{array}$ & $\begin{array}{c}0.82227 \\
\text { (strong) }\end{array}$ \\
\hline
\end{tabular}

\section{Table 10}

Possible associations between the different variables of the marketing communication mix

\begin{tabular}{|c|c|c|}
\hline Marketing communication mix variable..... & .....correlate with.... & $\begin{array}{c}r \geq 0.6 \\
p=0.0001 \\
\text { (strength) }\end{array}$ \\
\hline $\begin{array}{l}\text { Time-trend analyses of product awareness } \\
\text { (Importance) }\end{array}$ & $\begin{array}{l}\text { Cross impact between sponsorships and sales } \\
\text { (Importance) }\end{array}$ & $\begin{array}{l}0.74917 \\
\text { (moderate) }\end{array}$ \\
\hline $\begin{array}{l}\text { Time-trend analyses of product awareness } \\
\text { (Use) }\end{array}$ & $\begin{array}{l}\text { Cross impact between sponsorships and sales } \\
\text { (Use) }\end{array}$ & $\begin{array}{l}0.68961 \\
\text { (moderate) }\end{array}$ \\
\hline $\begin{array}{l}\text { Time-trend analyses of product awareness } \\
\text { (Use) }\end{array}$ & $\begin{array}{l}\text { Cross impact between sponsorships and sales } \\
\text { promotion (Use) }\end{array}$ & $\begin{array}{c}0.69232 \\
\text { (moderate) }\end{array}$ \\
\hline $\begin{array}{l}\text { Time-trend analyses of corporate image } \\
\text { enhancement (Use) }\end{array}$ & $\begin{array}{l}\text { Cross impact between sponsorships and } \\
\text { advertising (Use) }\end{array}$ & $\begin{array}{c}0.62871 \\
\text { (moderate) }\end{array}$ \\
\hline Increase in sponsors' name recall (Use) & $\begin{array}{l}\text { Cross impact between sponsorships and } \\
\text { advertising (Use) }\end{array}$ & $\begin{array}{c}0.65701 \\
\text { (moderate) }\end{array}$ \\
\hline $\begin{array}{l}\text { Cross impact between sponsorships and sales } \\
\text { (Importance) }\end{array}$ & $\begin{array}{l}\text { Cross impact between sponsorships and } \\
\text { sales promotion (Importance) }\end{array}$ & $\begin{array}{c}0.79328 \\
\text { (moderate) }\end{array}$ \\
\hline $\begin{array}{l}\text { Cross impact between sponsorships and sales } \\
\text { (Importance) }\end{array}$ & $\begin{array}{l}\text { Cross impact between sponsorships and } \\
\text { advertising (Importance) }\end{array}$ & $\begin{array}{c}0.60224 \\
\text { (moderate) }\end{array}$ \\
\hline $\begin{array}{l}\text { Cross impact between sponsorships and sales } \\
\text { (Importance) }\end{array}$ & $\begin{array}{l}\text { Return on investment in Rand value } \\
\text { (Importance) }\end{array}$ & $\begin{array}{c}0.61166 \\
\text { (moderate) }\end{array}$ \\
\hline $\begin{array}{l}\text { Cross impact between sponsorships and sales } \\
\text { (Use) }\end{array}$ & $\begin{array}{l}\text { Cross impact between sponsorships and sales } \\
\text { promotion (Use) }\end{array}$ & $\begin{array}{l}0.85180 \\
\text { (strong) }\end{array}$ \\
\hline $\begin{array}{l}\text { Cross impact between sponsorships and } \\
\text { sales promotion (Importance) }\end{array}$ & $\begin{array}{l}\text { Cross impact between sponsorships and public } \\
\text { relations (Importance) }\end{array}$ & $\begin{array}{c}0.66421 \\
\text { (moderate) }\end{array}$ \\
\hline $\begin{array}{l}\text { Cross impact between sponsorships and sales } \\
\text { promotion (Importance) }\end{array}$ & $\begin{array}{l}\text { Cross impact between sponsorships and } \\
\text { advertising (Importance) }\end{array}$ & $\begin{array}{c}0.66811 \\
\text { (moderate) }\end{array}$ \\
\hline
\end{tabular}




\begin{tabular}{|l|l|c|}
\hline Marketing communication mix variable..... & ....correlate with.... & $\begin{array}{c}\boldsymbol{r} \geq \mathbf{0 . 6} \\
\mathbf{p = 0 . 0 0 0 1} \\
\text { (strength) }\end{array}$ \\
\hline $\begin{array}{l}\text { Cross impact between sponsorships and public } \\
\text { relations (Importance) }\end{array}$ & $\begin{array}{l}\text { Cross impact between sponsorships and } \\
\text { advertising (Importance) }\end{array}$ & $\begin{array}{c}0.82227 \\
\text { (strong) }\end{array}$ \\
\hline $\begin{array}{l}\text { Cross impact between sponsorships and } \\
\text { public relations (Importance) }\end{array}$ & $\begin{array}{l}\text { Cross impact between sponsorships and } \\
\text { direct marketing (Importance) }\end{array}$ & $\begin{array}{c}0.65966 \\
\text { (moderate) }\end{array}$ \\
\hline $\begin{array}{l}\text { Cross impact between sponsorships and } \\
\text { public relations (Importance) }\end{array}$ & $\begin{array}{l}\text { Successful integration between different } \\
\text { sponsorships (Importance) }\end{array}$ & $\begin{array}{c}0.66011 \\
\text { (moderate) }\end{array}$ \\
\hline $\begin{array}{l}\text { Cross impact between sponsorships and } \\
\text { public relations (Use) }\end{array}$ & $\begin{array}{l}\text { Cross impact between sponsorships and } \\
\text { direct marketing (Use) }\end{array}$ & $\begin{array}{c}0.60951 \\
\text { (moderate) }\end{array}$ \\
\hline $\begin{array}{l}\text { Cross impact between sponsorships and } \\
\text { public relations (Use) }\end{array}$ & Hospitality success (Use) & $\begin{array}{c}0.68942 \\
\text { (moderate) }\end{array}$ \\
\hline $\begin{array}{l}\text { Cross impact between sponsorships and } \\
\text { advertising (Importance) }\end{array}$ & $\begin{array}{l}\text { Cross impact between sponsorships and } \\
\text { direct marketing (Importance) }\end{array}$ & $\begin{array}{c}0.77448 \\
\text { (moderate) }\end{array}$ \\
\hline $\begin{array}{l}\text { Cross impact between sponsorships and } \\
\text { advertising (Importance) }\end{array}$ & $\begin{array}{l}\text { Successful integration between different } \\
\text { sponsorships (Importance) }\end{array}$ & $\begin{array}{c}0.62001 \\
\text { (moderate) }\end{array}$ \\
\hline $\begin{array}{l}\text { Cross impact between sponsorships and } \\
\text { advertising (Use) }\end{array}$ & $\begin{array}{l}\text { Cross impact between sponsorships and direct } \\
\text { marketing (Use) }\end{array}$ & $\begin{array}{c}0.65370 \\
\text { (moderate) }\end{array}$ \\
\hline
\end{tabular}

\section{Figure 2}

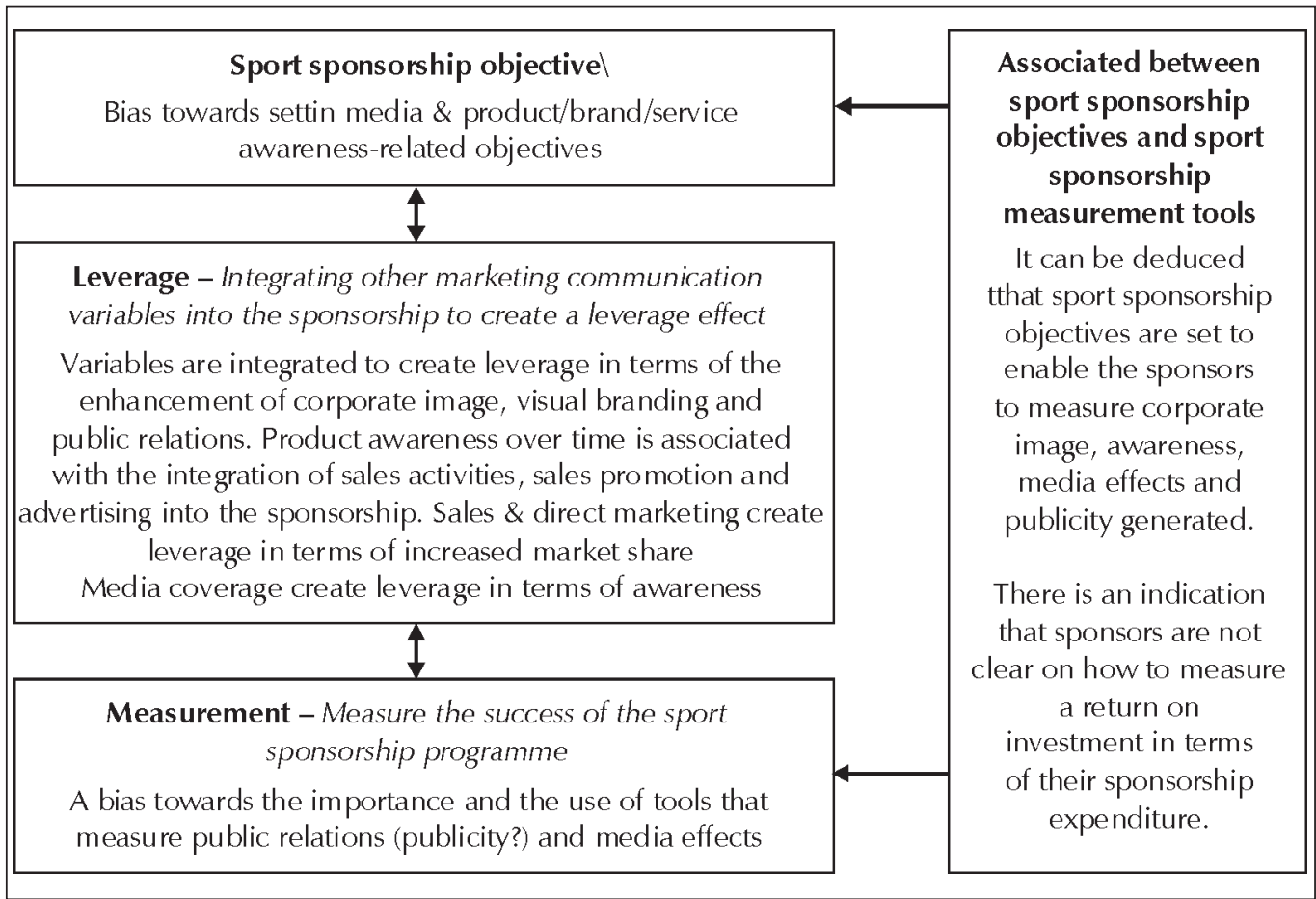


Associations between elements of the three key sponsorship decision-making areas

Table 10 shows moderate correlations between:

- Time trend analysis of product awareness with Cross impact between sponsorships and sales (Importance); Cross impact between sponsorships and sales (Use); Cross impact between sponsorships and sales promotion (Use); and Cross impact between sponsorships and advertising (Use).

- Public relations and Sales promotion and Public relations and Direct marketing in sport sponsorships.

- The Cross-impact between Advertising and Sales promotion, Advertising and Sales, and Advertising and Direct marketing.

Table 10 shows strong correlations between:

- The Cross-impact between Sales Promotion and Sales and The Cross-impact between Public relations and Advertising

Some association was detected between measuring how product awareness over time changes and the integration of sales activities, sales promotion and advertising. It can be concluded that public relations, advertising and sales promotion activities are regarded as important in creating a cross-impact in sport sponsorships (to leverage the effectiveness of the sponsorship). Figure 2 summarises the findings of the correlation analysis.

\section{6}

\section{Conclusion and recommendations}

Basic descriptive statistics revealed that the most important objectives set by the respondents are media and product/brand/service-related. The seven marketing communication mix variables regarded to be the most important by the respondents broadly cover corporate image, branding and public relations. The respondents mostly use media coverage-related tools to measure the success of their sponsorships. The correlation analysis confirmed that the respondents indicate some associations, between sponsorship objectives, integration of marketing communication variables and sponsorship evaluation.

It is recommended that the scope of sport sponsorship objective setting in South Africa should be widened to aid the effective measurement of sponsorship success. A general public relations category should be added and further divided into two separate sub-categories, namely corporate public relations and marketing public relations. This entails that practitioners should familiarise themselves with the differences in the definition, scope and domain of these two sub-categories. Objectives such as generating media coverage to aid corporate awareness, enhancing the corporate image and building stakeholder relations through guest hospitality should be included in the corporate public relations sub-category and generating brand publicity and increasing brand awareness should be included in the marketing public relations sub-category. The implication is that the product/brand/service category could be shrunk or totally excluded from the set of categories because brand sales or service use expansion (e.g. cellular organisations) objectives can be included in the sales-related category.

It is generally recommended that more discussion should be generated on alternative tools or techniques that can be used to measure sponsorship performance. It is suggested that the spotlight should be placed on measuring the effects of the sport sponsorship. The following effects can serve as initial focus areas (an example or application is offered in parenthesis):

- Brand - (increase preference for the sponsor's brand);

- Sales - (increase sales).

- Stimuli - (arousal, involvement and pleasure).

- Recall - (inter alia increase recall of sponsor's name, logo, slogan).

- Image - (enhance corporate image).

- Positioning - (position new sponsor's involvement).

- Media - (quantity and quality of publicity generated). 
- Awareness - (increase sponsorship awareness).

- Relationship - (increase in relationshipbuilding among selected stakeholders).

- Association - (associate sponsor with friendliness, goodness or closeness to community).

- Attitude - (attitude towards sponsee).

- Integrated marketing communication (ability to integrate a selection of marketing communication mix variables and measuring the effect on each).

- Recognition - (familiarity tracking).

By focusing on effects sponsors would be able to set more measurable and appropriate objectives and also enable them to leverage their sponsorship more effectively. The size and scope of sport sponsorship expenditure in South Africa warrants more research into effective decision-making with a particular focus on measuring the effectiveness of the sponsorship expenditure.

\section{References}

1 ABRATT, R. \& GROBLER, P. (1989) "The evaluation of sports sponsorship", International Journal of Advertising, 8: 351-62.

2 ABRATT, R., CLAYTON, B. \& PITT, L. (1987) "Corporate objectives in sports sponsorship", International Journal of Advertising, 6: 299-311.

3 ACZELL, A.D. (1999) Complete Business Statistics, McGraw-Hill: Boston, USA.

4 ARANI, A. (1992) "How corporations can take advantage of Olympic marketing opportunities", Sport Marketing Quarterly, 1(1): 7-12.

5 BRASSINGTON, F. \& PETTITT, S. (2000) Principles of Marketing, ( $2^{\text {nd }}$ ed.) Financial Times - Prentice Hall: Harlow, England, UK.

6 BURNS, A.C. \& BUSH, R.F. (1998) Marketing Research, $\left(2^{\text {nd }}\right.$ ed.) Prentice Hall: New Jersey, USA.

7 CORNWELL, T.B. \& MAIGNAN, I. (1998) "An international review of sponsorship research", Journal of Advertising, Spring, XXVII(1): 1-21.

8 CRIMMINS, J. \& HORN, M. (1996) "Sponsorship: From management ego trip to marketing success", Journal of Advertising Research, 36(4): 11-21.
9 CUNEEN, J. \& HANNAN, M.J. (1993)

"Intermediate measures and recognition testing of sponsorship at an LPGA Tournament", Sport Marketing Quarterly, 2(1): 47-56.

10 D'ASTOUS, A. \& BITZ, P. (1995) “Consumer evaluations of sponsorship programmes", European Journal of Marketing, 29(12): 6-22.

11 EYLES, N. (2001) "Reklamebedryf kan krimp". Sake-Rapport, 29 April: 3.

12 HANSEN, F. \& SCOTWIN, L. (1995) "An experimental enquiry into sponsorship: What effects can be measured?", Marketing and Research Today, August: 173-81.

13 IRWIN, R.L. \& ASIMAKOPOULOS, M.K. (1992) "An approach to the evaluation and selection of sport sponsorship proposals", Sport Marketing Quarterly 1(2): 43-51.

14 IRWIN, R.L. \& SUTTON, W.A. (1994) "Creating the ideal sponsorship arrangement: An exploratory analysis of relationships existing between sport sponsorship inventory criteria and sponsorship objectives", In World Marketing Congress Proceedings, Grant, K. \& Walker, I. (eds.) Australia, Academy of Marketing Science, 7(3): 15.113-15.127.

15 JAVALGI, R., TRAYLOR, M., CROSS, A. \& LAMPMAN, E. (1994) "Awareness of sponsorship and corporate image: An empirical investigation", Journal of Advertising, 23(4): 47-58.

16 JEANNET, J. \& HENNESSEY, H.D. (1995)

Global Marketing Strategies, (3 ${ }^{\text {rd }}$ ed.) HoughtonMifflin Company: Boston, USA.

17 KITCHEN, P.J. (1999) Marketing Communications: Principles and Practice, Thomson Business Press: London, UK.

18 KOENDERMAN, T. (2000) "Sponsorship racing ahead", Financial Mail, March 24: 86/87.

19 MARSHALL, D.W. \& COOK, G. (1992) “The corporate (sports) sponsor", International Journal of Advertising, 11: 307-24.

20 MEENAGHAN, T. (1991) "The role of sponsorship in the marketing mix", International Journal of Advertising, 10(1): 35-47.

21 MEENAGHAN, T. (1994) "Point of view: Ambush marketing: Immoral or imaginative practice?", Journal of Advertising Research, September/October: 77-88.

22 PARKER, K. (1991) Sponsorship: "The research contribution", European Journal of Marketing, 25(11): 22-30.

23 POPE, N.K.L. \& VOGES, K.E. (1997) "Awareness of Sponsorship and Corporate Image: An Investigation Replicated", work in progress, Griffith University. 
24 POPE, N. (1998) "Overview of current sponsorship thought", The Cyber-Journal of Sport Marketing, 2(1): 1

25 QUESTER, P. \& BURTON, R. (1997) "Awareness as a measure of sponsorship effectiveness: The Adelaide Formula One Grand Prix and evidence of incidental ambush effects", Journal of Marketing Communications, 3(1): 120.

26 RAJARETNAM, J. (1994) “The long-term effects of sponsorship", Marketing \& Research Today, February: 62-74.

27 SANDLER, D.M. \& SHANI, D. (1993) "Sponsorship and the Olympic Games: The consumer perspective", Sport Marketing Quarterly, 2(3): 38-43.

28 SHILBURY, D. \& BERRIMAN, M. (1996) "Sponsorship awareness: A study of St. Kilda Football Club supporters", Sport Marketing Quarterly, 5(1): 27-35.

29 SHIMP, T. (1997) Promotion Management and Marketing Communication (4 ${ }^{\text {th }}$ ed.) Dryden Press: Harcourt Brace \& Company, USA.

30 SLEIGHT, S. (1989) Sponsorship: What It Is and How to Use It, McGraw-Hill: Maidenhead.

31 SPEED, R. \& THOMPSON, P. (1997) "Developing a model of the determinants of sports sponsorship impact”, Paper presented at the 1997 European Marketing Academy
Conference at Warwick Business School, UK, May 20-23.

32 STIPP, H. \& SCHIAVONE, N. (1996) "Modelling the impact of Olympic sponsorship on corporate image", Journal of Advertising Research 36(4): 22-28.

33 STOTLAR, D. \& JOHNSON, D. (1989) "Assessing the impact and effectiveness of stadium advertising on sport spectators at division 1 institutions", Journal of Sport Management, 3: 90-102.

34 STOTLAR, D. (1993) "Sponsorship and the Olympic Winter Games”, Sport Marketing Quarterly, 2(1): 35-43.

35 THWAITES, D. (1995) "Professional football sponsorship - Profitable or profligate?" International Journal of Advertising, 14: 149-64.

36 VAN HEERDEN, C.H. (2003) "Sport sponsorship decision-making in South Africa should go beyond media coverage and brand awareness", Paper read at the 12th Annual Employee and Corporate Communications Conference on 27 February at Johannesburg International Airport.

37 WITCHER. B., CRAIGEN, J.G., CULLIGAN, D. \& HARVEY, A. (1991) "The links between objectives and function in organizational sponsorship", International Journal of Advertising, 10: 13-33. 